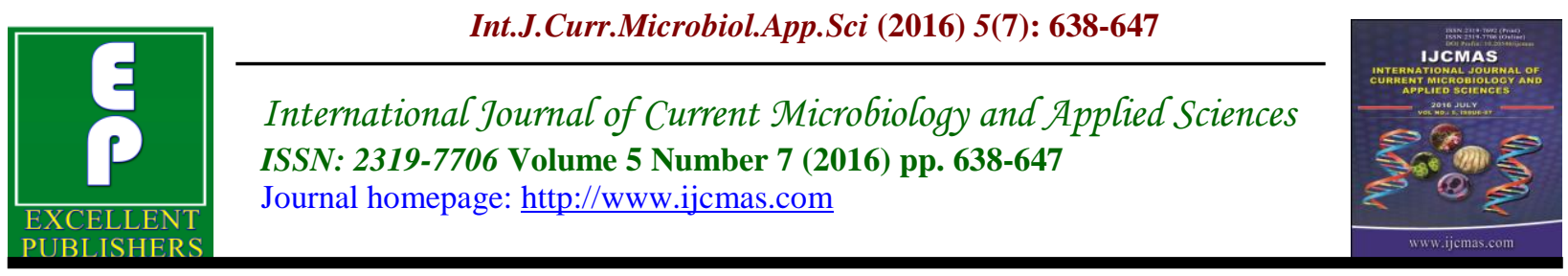

Original Research Article

http://dx.doi.org/10.20546/ijcmas.2016.507.072

\title{
Impact of Heavy Metal, Chromium on Protein Metabolism in Brain and Muscle of Freshwater Fish, Channa striatus (BLOCH)
}

\author{
R. Palaniappan ${ }^{1}$ and M. Muthulingam ${ }^{2} *$ \\ ${ }^{1}$ Manonmaniam Sundaranar University, Abishekapatti, Tirunelveli, 627 012, Tamilnadu, India \\ ${ }^{2}$ Department of Zoology, Faculty of Science, Annamalai University, Annamalainagar 608002 , \\ Tamilnadu, India \\ *Corresponding author
}

Keywords

Brain, amino acid, chromium, Channa striatus, muscle, protein

Article Info

Accepted:

20 June 2016

Available Online:

10 July 2016

\section{A B S T R A C T}

Major adverse effects on environmental quality, ecosystem integrity and human health have often been associated with mismanagement of chemical materials and the eliminations of hazardous substances. Heavy metals from geological and anthropogenic sources are increasingly being released into natural waters. Contamination of aquatic ecosystems with heavy metals has seriously increased worldwide attention. Heavy metals present in effluents discharged by the leather industries constitute the most common group of toxic and non-degradable substances. On reaching the aquatic ecosystem, they pose a serious threat to the biotic living there in especially fish. Fishes have a great significant in the life of mankind, being a most important source of protein and providing other useful products. The aim of the present study was to assess the protein and amino acid levels in brain and muscle of Channa striatus was exposed to sublethal concentrations of chromium for the period of 10, 20 and 30 days. The fish exposed to chromium showed a decrease the protein and increase the amino acid levels for 10, 20 and 30 days in brain and muscle. The objective of the present investigation was to observe the effect of chromium on protein and amino acid levels in the brain and muscle of freshwater fish, Channa striatus.

\section{Introduction}

Environmental pollutants, such as heavy metals, economic poison like pesticides, effluents from industries pose serious risks to many aquatic organisms. The world wide problem is the environmental pollution and most important pollutants are the heavy metals in aquatic network because of their toxicity, accumulation and biomagnification by aquatic creatures. Domestic, industrial and anthropogenic activities may broadly become the source of natural aquatic systems contamination with heavy metals (Conacher and Mes, 1993; Velez and Montoro, 1998; Afshan et al., 2014). Water pollution by heavy metals, especially chromium pollution from industrial sources can affect aquatic life, all ecosystems and human health directly or through food chain. Heavy metals are introduced into the environment by a wide spectrum of natural sources such as 
volcanic, erosion and anthropogenic activities including industrial wastes as well as a leakage (Yilmaz et al., 2010). Water pollution is defined as introduction by man, directly or indirectly, of substances or energy to the aquatic environment resulting in deleterious effects such as hazards to human health, hindrance of fish activities and impairment of water quality. A human activity causes contamination of aquatic medium leads to spoil the aquatic life of flora and fauna especially fish. The industrial effluent containing heavy metal like mercury, chromium, lead, cadmium, nickel and arsenic enormously released without treatment nearby river, lake, pond and sea. The aquatic organisms are very much affected due to heavy metal.

Heavy metal pollution of the aquatic medium has long been recognized as a serious environmental problem. Heavy metals reach to the aquatic environment from natural and anthropogenic sources and distributed in the water bodies, suspended solids and sediments during the course of their transportation (Olajire and Imeokparia, 2001; Adeniyi et al., 2005; Aderinola et al., 2009). The consequence of heavy metal pollution can be hazardous to man and it often becomes mandatory to check chemical contaminants in foods from the aquatic environment to understand their hazard levels. Heavy metals like chromium proven to be persistent pollutants. Though present in traces heavy metals tend to bioaccumulate and biomagnifying. Their accumulation in biotic tissues causes toxic effects. Chromium is considered as a heavy metal and pollutant as well as an essential micronutrient. Wastewater pollution by chromium originating from electroplating, dyeing, tannery, hard alloy steel and stainless steel manufacture, has affected the life on earth. Chromium is also used as a catalyst and coating material (Idachaba et al., 2004). Welding, grinding and polishing of stainless steel are among principal ways of introducing chromium into the land environment while other ways of introducing chromium into air and water environments include the burning of fossil fuels and waste incineration (WHO, 1988). This pollution could affect all ecosystems and human health directly or through food chain (Y1lmaz et al., 2009). Chromium exists in different oxidation states which have distinct biological effects (Richard, 1991). Hexavalent chromium (Cr VI) is a well known carcinogen metal form for animals and human beings. $\mathrm{Cr}$ (VI) compounds readily penetrate into cell membranes via anion transport systems. Fish are often at the top of the aquatic food chain and affected by heavy metals which is present in the waste water from industries (Mansour and Sidky, 2002).

Human beings have been exposed to heavy metals through food chain. Industrialization of the world has dramatically increased the overall environmental 'load' of heavy metal toxins to the point that our societies are dependent upon them for proper functioning. Now a day, heavy metals are abundantly available in our environmental condition due to increased use of these compounds in the industries. It is very difficult to avoid exposure to harmful heavy metals that are so prevalent in our environment. Human consuming more fish that may be collected from polluted area. The heavy metal enters through food chain especially fish to reach human beings and may cause metabolic diseases, nervous disorder, headache, vomiting and cancer. Heavy metal chromium contributes to a variety of adverse health effects. Hence, the present investigation was to assess the protein and amino acid content in brain and muscle of Channa striatus exposed to sublethal concentrations of chromium. 


\section{Materials and Methods}

The fish Channa striatus having mean weight $18-22 \mathrm{~g}$ and length $13-15 \mathrm{~cm}$ were collected from PSP fish farm, at Puthur and acclimatized to laboratory conditions. They were given the treatment of $0.1 \% \mathrm{KMNO} 4$ solution and then kept in plastic pools for acclimatization for a period of two weeks. They were fed twice daily i.e. morning and evening on boiled chicken eggs approximately $4 \%$ of fish body weight divided into two equal meals daily. The chromium was used in this study and stock solutions were prepared. Chromium, $\mathrm{LC}_{50}$ was found out for $96 \mathrm{~h}$ (34 ppm) (Sprague, $1971)$ and $1 / 20^{\text {th }}(1.7 \mathrm{ppm}), 1 / 15^{\text {th }}(2.27$ $\mathrm{ppm})$ and $1 / 10^{\text {th }}(3.4 \mathrm{ppm})$ taken as sublethal concentrations for this study. Forty fish were selected and divided into 4 groups of 10 each. The first group was maintained in free from chromium and served as the control. The other 3 groups were exposed to sub lethal concentration of chromium, 10 litre capacity aquaria. The $2^{\text {nd }}, 3^{\text {rd }}$ and $4^{\text {th }}$ groups were exposed to chromium, for 10, 20 and 30 days respectively. At the end of each exposure period, the fish were sacrificed and the required tissues were collected for protein and amino acid estimation. The protein and amino acid content in brain and muscle of Channa striatus were estimated by the method of Lowry et al., 1951 and Moore and Stein (1954) respectively. The data obtained were analyzed by applying analysis of variance DMRT one way ANOVA to test the level of significance (Duncan, 1957).

\section{Results and Discussion}

\section{Protein level in brain}

The protein contents were observed in the control brain to be $82.83 \pm 5.94,83.64 \pm$ 6.00 and $84.21 \pm 6.05 \mathrm{mg} \mathrm{g}^{-1}$ wet weight for 10, 20 and 30 days respectively. The protein contents were significantly decreased when the fish Channa striatus exposed with low $(78.51 \pm 5.61,73.69 \pm$ 5.25 and $68.69 \pm 4.87$ ), medium ( $75.65 \pm$ $5.40,69.11 \pm 4.90$ and $65.33 \pm 4.61)$ and high $(73.89 \pm 5.26,66.75 \pm 4.71$ and 60.62 \pm 4.25 ) sublethal concentrations of heavy metal chromium for 10, 20 and 30 days respectively (Fig 1).

\section{Protein Level in Muscle}

The protein contents were observed in the control muscle to be $76.71 \pm 5.48,77.63 \pm$ 5.54 and $77.79 \pm 5.56 \mathrm{mg} \mathrm{g}^{-1}$ wet weight for 10,20 and 30 days respectively. The protein contents were significantly decreased when the fish Channa striatus exposed with low $(74.69 \pm 5.32,71.83 \pm$ 5.10 and $66.63 \pm 4.71$ ), medium (73.12 \pm $5.20,69.65 \pm 4.91$ and $64.67 \pm 4.56)$ and high $(70.85 \pm 5.03,67.71 \pm 4.79$ and 60.59 \pm 4.25 ) sublethal concentrations of heavy metal chromium for 10, 20 and 30 days respectively. The decrease in the protein content of the liver was more in 30 days of exposed fish compared to 10 and 20 days (Fig $1)$.

\section{Amino Acid Level in Brain}

The amino acid contents were observed in the control brain to be $3.60 \pm 0.27,3.62 \pm$ 0.27 and $3.57 \pm 0.27 \mathrm{mg} \mathrm{g}^{-1}$ wet weight for 10,20 and 30 days respectively. The amino acid contents were significantly increased when the fish Channa striatus exposed with low $(3.97 \pm 0.30,4.58 \pm 0.35$ and $6.06 \pm 0.46$ ), medium ( $4.34 \pm 0.33$, $4.92 \pm 0.37$ and $6.58 \pm 0.50)$ and high $(5.08 \pm 0.39,5.77 \pm 0.44$ and $7.94 \pm 0.60)$ sublethal concentrations of heavy metal chromium for 10,20 and 30 days respectively. In sublethal concentrations of 
heavy metal chromium exposed fish, Channa striatus the amino acids showed a gradual increase from 10 to 30 days. The maximum increase was noticed in high sublethal concentration of heavy metal chromium at 30 days of exposure periods (Fig 2).

\section{Amino Acid Level in Muscle}

The amino acid contents were observed in the control muscle to be $3.42 \pm 0.26,3.40 \pm$ 0.26 and $3.43 \pm 0.26 \mathrm{mg} \mathrm{g}^{-1}$ wet weight for 10, 20 and 30 days respectively. The amino acid contents were significantly increased when the fish Channa striatus exposed with low $(3.96 \pm 0.29,4.44 \pm 0.34$ and $4.98 \pm$ 0.38 ), medium ( $4.40 \pm 0.33,4.77 \pm 0.36$ and $5.34 \pm 0.40)$ and high $(4.57 \pm 0.31,5.51 \pm$ 0.42 and $6.66 \pm 0.51 \quad$ ) sublethal concentrations of heavy metal chromium for 10, 20 and 30 days respectively. In sublethal concentrations of heavy metal chromium exposed fish, Channa striatus the amino acids showed a gradual increase from 10 to 30 days. The maximum increase was noticed in high sublethal concentration of heavy metal chromium at 30 days of exposure periods (Fig 2).

The rapid industrialization is one of the major causes of water pollution. The discharges of untreated and partially treated wastewater from various industries like chemical, pesticides, fertilizer, pulp and paper and sugar etc., have polluted the aquatic bodies such as river, pond and ditches. In India about two tones wastewater is discharged into aquatic bodies annually from industries (Shaffi, 1981). Discharges of industrial wastewater, cause serious consequence for fisheries resulting in impairment of important function such as respiration and osmoregulation (Kumaraguru, 1995; Yadav et al., 2007). Toxicants produce many physiological and biochemical changes in freshwater organisms by influencing their activities. Alterations in the chemical composition of the natural aquatic environment usually affect behavioral and physiological systems of the inhabitants, particularly those of the fish (Radhaiah et al.,1987). Fish mortality due to toxicant exposure mainly depends upon its sensitivity to the toxicant, its concentration and duration of exposure (Ram et al., 2009). The detection of abnormal activity is based on comparisons of the responses of exposed fish, either with activity measured during a baseline or preexposure period or observations of fish under a control treatment (Richmond and Dutta, 1992). The natural physiological functioning of an organism gets disturbed on exposure to toxicant stress. It induces its effect first at cellular or even at molecular level, but ultimately causes physiological, pathological and biochemical alterations. It is, therefore necessary to focus attention on changes in biochemical composition of organisms, which are constantly under pollutant threat (Venkata Rathinamma and Nagaraju, 2013). Pollutants enter the fish body through a number of routes: directly through the digestive tract due to consumption of contaminated water and food or non-dietary routes across permeable membranes such as the gill or skin (Burger et al., 2002; Banaee et al., 2013).

Fishes are major sources of protein. They constitute major components of most aquatic habitats acting as bio-indicator of heavy metal levels in the aquatic environment (Banaee et al., 2013). Proteins are involved in major physiological events therefore the assessment of the protein content can be considered as a diagnostic tool to determine the physiological phases of organism. Proteins are highly sensitive to heavy metal poisoning (Jacobs et al., 1977). Protein are of the most important and complete group of biological material comprising of 
nitrogenous constituents of the body and performing different function, proteins are involved in several major physiological events. Therefore the assessment of protein content can be considered as a diagnostic tool to determine the physiological phases of organisms.

The amino acids are the basic building block of all proteins. Those amino acids which exist in free from in tissues and not bound to proteins are called as free amino acids. Normally during diseased conditions in plants and animals there will be a change in the total free amino acids composition. Hence the estimation of total free amino acid gives as indication about the physiological and health condition of animal (Bais and Lokhande, 2012).

The present investigation, in the brain and muscle protein content had decreased whereas amino acids content had increased at all periods of exposure when Channa striatus was exposed with sublethal concentrations of chromium for the periods of 10, 20 and 30 days exposure. The free amino acid pool was increased in the tissues of the fish during exposure to lihocin (Abdul et al., 2010), while the elevated free amino acid contents were utilized for energy production by supplying them as keto acids into TCA cycle through aminotransferases to contribute energy needs during toxic stress. Increased free amino acid levels were the result of breakdown of protein for energy and impaired incorporation of amino acids in protein synthesis (Singh et al., 1996).

The decrease the protein and lipid might be partly due to their utilization in cell repair and tissue organization with the formation of lipoproteins which are important cellular constituents of cell membranes and cell organelles present in the cytoplasm (Harper,
1963). Increase in free amino acid in protein synthesis (Singh et al., 1996). It is also attributed to lesser use of amino acids (Seshagiri, Rao et al.,1987) and their involvement in the maintenance of an acid base balance (Moorth et al., 1984; Natarajan, 1985) suggested that stress conditions induce elevation in the transamination pathway. The decreases in the total protein level and increases in the total free amino acid level in liver and muscle suggest the high protein hydrolytic activity due to elevation of protease activity (Zodape, 2011). Simillarly Senthil Elango and Muthulingam (2014) suggested that declining trends of protein and elevated levels of amino acid in brain and muscle of Oreochromis mossambicus was exposed to sublethal concentrations of chromium. The protein content decreased in the liver, brain and kidney tissues of Channa punctatus during lihocin treatment (Abdul et al., 2010).

Satyaparameshwar et al., (2006) suggested that Lamellidens marginalis exposed to sublethal concentration of chromium showed decrease the protein and RNA where as amino acid level was elevated. The decreased protein level was observed in the kidney tissue of Catla catla at sublethal concentration of chromium (Vincent et al., 1995).

Muscle rich in proteins, forms mechanical tissue intended for mobility and do not participate in metabolism. Liver being the centre for various metabolisms is also rich in proteins. In the gill, liver, kidney, heart and brain tissues of the exposed fish, the total protein content was found to be reduced (Sobha et al., 2007). Protein and glycogen contents were decreased in gill, muscle and intestine of Zebra fish, Danio rerio exposed to sublethal concentration of mercuric chloride (Vutukuru and Kalpana, 2013). 
Fig.1 Protein levels changes $(\mathrm{mg} / \mathrm{g})$ in brain and muscle of Channa striatus exposed to sublethal concentrations of chromium
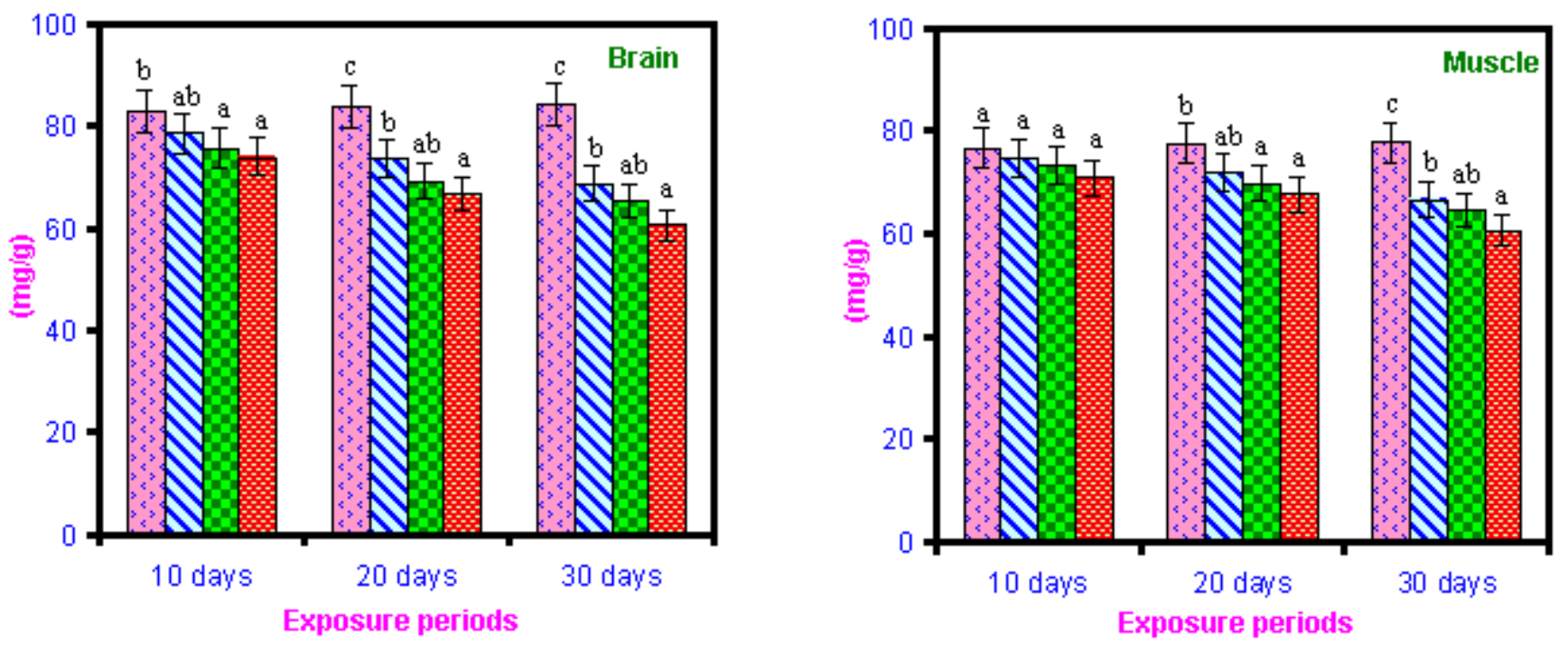

I - Standard deviation

Control $\mathbf{\Delta}$ Low concentration $\mathbf{B}$ Medium concentration 畻 High concentration

Fig.2 Amino acid (mg/g) in brain and muscle of Channa striatus exposed to sublethal concentrations of chromium
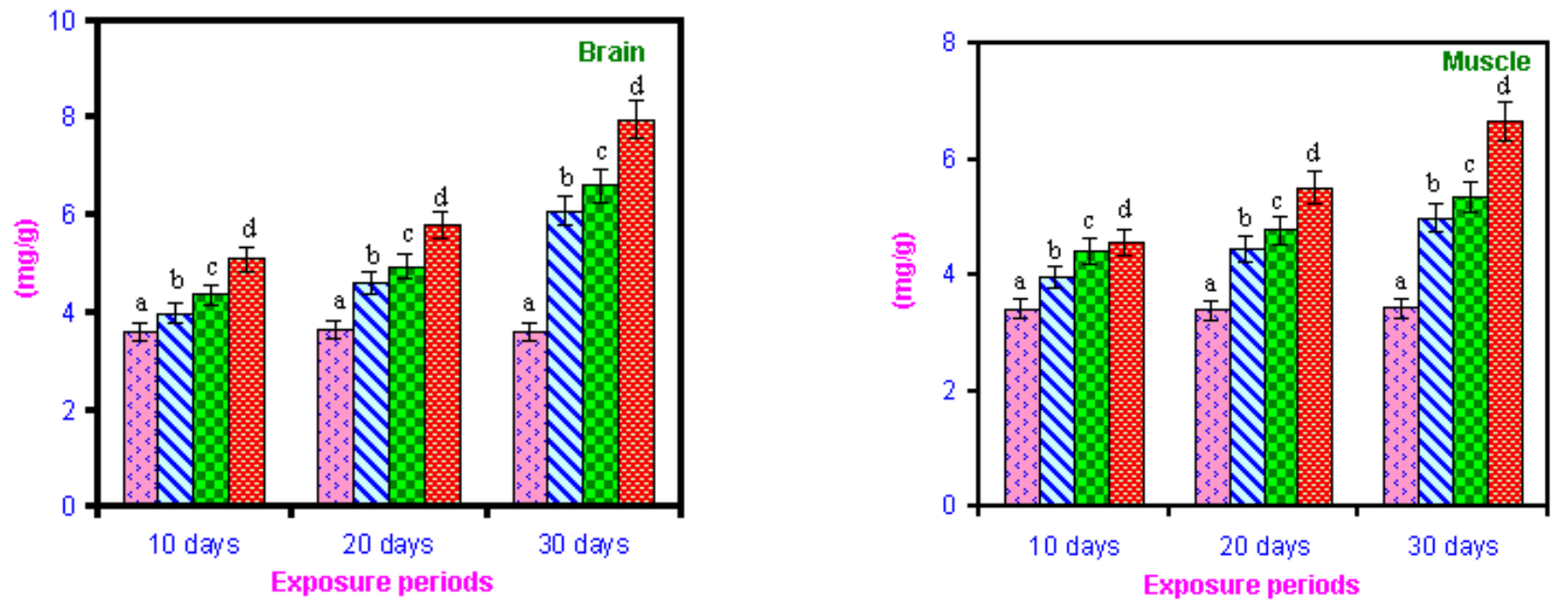

I - Standard deviation

Control $\mathbf{\Delta}$ Low concentration $\mathbf{D}$ Medium concentration 圈 High concentration 
Many investigators have also recorded such a reduction in protein content in fishes exposed to different toxicants. A reduction in the protein content in the present investigation in Channa striatus exposed to sublethal concentrations suggests that the tissue protein undergoes proteolysis, which results in an increase in the production of free amino acids. These amino acids are utilized for energy production during stressful situation in the intoxicated fishes. Anitha et al., (2014) reported that freshwater fish, Labeo rohita treated with sub lethal concentrations of Fosmite shows depletion of total protein content in brain, muscle, gill, liver and kidney. The total protein and glycogen content reduced in muscle, brain, liver, kidney, gill and gut of Labeo rohita exposed to sublethal concentration of phenthoate (Somaiah et al., 2014). The two sublethal concentration of azodrin exposure results show that decrease in the level of protein content in brain, muscle, ovary, intestine, gills and liver (Janardana Reddy et al., 2016). Protein, glycogen and lipid contents were decreased in gill, liver, kidney and muscle of Labeo rohita after acute and chronic exposure to textile mill effluent (Nikalje et al., 2011). Depletion of protein content has been observed in the muscle, intestine and brain of the fish Catla catla as a result of mercury chloride toxicity (Martin Deva Prasath and Arivoli, 2008). Protein and glycogen contents were decreased whereas amino acid and glucose levels increased in gill, liver, kidney and muscle of Cirrhinus mrigala exposed to sublethal concentration of nickel for the periods of 7, 14, 21 and 28 days (Parthipan and Muniyan, 2013). The protein content was decreased in liver, brain and kidney of Channa punctatus during sublethal concentration of triazophos (Naveed et al., 2010). The level of total protein content was found to decrease in the liver and muscle tissues of fish, Labeo rohita were exposed to arsenic (Zodape,
2010). Declining trends in protein, lipid and glycogen contents whereas amino acid level and protease activity was elevated in liver and muscle of the fish, Labeo rohita exposed to sublethal concentration of zinc (Zodape, 2011). Protein and lipid content of vital organs like gill, liver, muscle and kidney depleted in exposed to chromium (Arillo et al., 1982; Sastry and Sunitha, 1984; Ambrose et al., 1994). Moorthikumar and Muthulingam (2010) noticed that decline in the protein and elevated contents of amino acid in liver, kidney and brain of Labeo rohita under heavy metal, nickel chloride stress. It is evident that proteins are degraded to meet the energy requirements during sublethal concentrations of chromium. The depletion in protein level was due to diversification of energy to meet the impending energy demand when the fish Channa striatus exposed to sublethal concentrations of heavy metal chromium.stress. The reduction in protein content in the present study indicates that the tissue protein undergoes proteolysis resulting in the production of free amino acids leads to disturbances in the physiological activity of the fish Channa striatus.

\section{Acknowledgement}

The authors wish to thank the authorities of Manonmaniam Sundaranar University and Professor and Head, Department of Zoology, Annamalai University for providing the facilities to carry out the work.

\section{References}

Adeniyi, A.A., Okedeyi, O.O and Idowu A.B., 2005. Determination of cadmium, chromium and lead in dumpsite soil and millipede (Parajulus sp). Ghana Journal of Chemistry, 6:17-26.

Aderinola, O.J., Clarke, E.O., Olarinmoye, O.M., Kusemiju, V and Anatekhai, M.A., 2009. Heavy metals in surface 
water, sediments, fish and Perwinkles of Lagos Lagoon. Journal of Agriculture and Environmental Science, 5(5): 609617.

Afshan,S., Ali, S., Ameen, U.S., Farid, M., Bharwana, S.A., Hannan, $F$ and Ahmad, R., 2014. Effect of Different Heavy Metal Pollution on Fish, Research Journal of Chemical and Environmental Sciences, 2(2): 35-40.

Ambrose, T., Cyril Arunkumar, L., Vincent, S and Roselyn, L., 1994. Biochemical response of Cyprinus carpio communis to toxicity of tannery effluent. J. Ecobiol., 6(3): 213 - 216.

Anitha, A., Venkatarathnamma, $\mathrm{V}$ and Jagadish Naik, M., 2014. Effect of fosmite (50\% EC) an organiophosphate in protein levels of fresh water fish Lobeo rohita (Hamilton) J. Atoms and Molecules, 4(6): 815 - 821.

Arillo, A., Margiocco, C., Melodia, F and Mensi, P., 1982. Biochemical effects of long term exposure to chromium, cadmium and nickel. M. Rainbow trout, Salmo gairdneril, Chemosphere, 11:47 -58 .

Bais U.E. and Lokhande M.V., 2012. Effect of Cadium Chloride on the Biochemical content in different tissues of the freshwater fish, Ophicephalus striatus International Research Journal of Biological Sciences, 1(7), 55-57.

Banaee, M., Nematdoust Haghi, B and Zoheiri, F., 2013. LC50 and bioaccumulation of lead nitrate $(\mathrm{Pb}(\mathrm{NO} 3) 2)$ in Goldfish (Carassius auratus). International Journal of Aquatic Biology, 1(5): 233-239.

Burger J., Gaines K.F., Boring C.S., Stephens W.L., Snodgrass J., Dixon C., McMahon M., Shukla S., Shukla T and Gochfeld, M., 2002. Metal levels in fish from the Savannah River: Potential hazards to fish and other receptors. Environmental Research, 89: 85-97.

Conacher, H and Mes, J., 1993. Assessment of human exposure to chemical contaminants in foods. Food Addit.
Cont.10:5-15.

Dawoud, A. S., Habib, S. A and Shehata, S.A., 2009. Clinicopathological studies on the effect of heavy metals pollution on DNA and RNA content in catfish, Egypt. J. Comp. Path and Clinic. Path. 22(2): $18-40$.

Duncan, B.D., 1957. Multiple range tests for correlated and heteroscedastic means. Biometrics, 13: 359 - 364 .

Harper,A.H., 1963. Review of Physiological chemistry. Language medical publications Co. Ltd, Japan.

Idachaba, M.A., Nyavor, K and Egiebor, N.O., 2004. The leaching of chromium from cementbased waste form via a predominantly biological mechanism. Adv. Environ. Sci. Res. 8: 483-491.

Jacobs, J. M., Carmicheal, N., Cavanagh, J. B., (1977). Ultra structural changes in the nervous system of rabbits poisoned with methyl mercury. Toxical. Appl. Pharmocol., 39: 249-261.

Janardana Reddy, S., Vineela, D and Kiran Kumar,B., 2016. Impact of azodrin on protein content in the freshwater fish, Catla Catla, Int. Journal of Engineering Research and Applications.6(2):92-96.

Kumaraguru, A.K.: Water pollution and fisheries. Ecol. Environ. Cons., 1, 143150 (1995).

Lowry, O.H., N.J. Rosebrough, A.L. Farr and R.J. Randall, 1951. Protein measurement with the Folin-phenol reagent. J. Biol. Chem., 193: 265-275.

Mansour, S.A and Sidky, M.M., 2002. Ecotoxicologcal Studies. 3. Heavy metals contaminating water and fish from Fayoum Governorate, Egypt. Food Chem. 78: 15-22.

Martin Deva Prasath, P and Arivoli, S., 2008. Biochemical study of freshwater fish catla catla with reference to mercury chloride, Iran. J. Environ. Health. Sci. Eng., 5(2):109-116 .

Moore, S. and W.H. Stein, 1954. A modified ninhydrin reagent for the photometric determination of amino acid and related compounds. J. Biol. Chem., 211: 907- 
913.

Moorthikumar, $\mathrm{K}$ and Muthulingam , M., 2010. Shifts in protein metabolism in liver, kidney and brain of Indian major carp, Labeo rohita (Hamilton) under heavy metal, nickel chloride stress. International Journal of Current Research, 7: 014-017.

Moorthy. K.S., Kashi Reddy, B., Swamy, K.S and Chethy, C.S., 1984. Changes in respiration and ionic content in the tissues of freshwater mussel exposed to methyl parathion toxicity. Toxicological Letters. $21: 287-291$.

Natarajan, G.M., 1985. Inhibition of branchial enzymes in snake head fish, Channa striatus by oxy demetom methyl. Pesticide Biochemistry and Physiology, 23: 41-46.

Naveed, A., Venkateshwarlu, P and Janaiah, C., 2010. Impact of sublethal concentration of triazophos on regulation of protein metabolism in the fish Channa punctatus (Bloch), African Journal of Biotechnology, 9(45): 77537758

Nayan Singh,R., Kumar Pandey, R., Nath Singh, N and Krishna Das, V., 2009. Acute Toxicity and Behavioral Responses of Common Carp, Cyprinus carpio (Linn.) to an Organophosphate Dimethoate).World J. Zool. 4 (2): 7075.

Nikalje,S.B., Muley, D.V., Pailwan, I.F and Angadi, S.M., 2011. Biochemical alterations in different tissues of a freshwater major carp Labeo rohita after acute and chronic exposure to textile mill effluent (TME),The Ecoscan,1(spl):341-345.

Olajire, A.A and Imeokparia, F.E., 2001. Water quality assessment of Osun River: Studies on inorganic nutrients. Environmental Monitoring Assessment, 69(1): 17-28.

Parthipan, P and Muniyan, M., 2013. Effect of nickel on certain biochemical parameters in selected tissues of Cirrhinus mrigala, International Journal of Modern Research and Reviews, 1(10):24-34.

Radhaiah, V., Girija, M and Rao, K.J., 1987. Changes in selected biochemical parameters in the kidney andblood of the fish, Tilapia mossambica (Peters), exposed to heptachlor. Bull. Environ. Contam. Toxicol. 39: 1006-1011.

Richard, C.F and Bourg, C.M.A., 1991. Aqueous geochemistry of chromium: A review. Water Res. 25(7): 807-816.

Richmonds, C and Dutta, H.M., 1992. Effect of Malathion on the optomotor behavior of bluegill sun fish. Lepomis macrochirus. Comparative Biochem and Physiol.102: 523-526.

Sastry, K.V and Sunitha, K., 1984. Chronic toxic effects of chromium in Channa punctatus, Biochemical studies. J. Environ. Bio., 5(1): 53 - 56.

Senthil Elango, P and Muthulingam, M., 2014. Impact of heavy metal chromium on protein and aminoacid contents in brain and muscle of freshwater fish Oreochromis mossambicus (Peters), International Journal of Current Research, 6( 01): 4841-4845.

Seshagiri Rao, K., Srinivas, K., Kashi Reddy, B., Swamy, K.S and Chethy, C.S., 1987. Effect of benthiocarb on protein metabolism of teleost, Sarotherodon mossambica. Indian Journal of Environmental Health, 29: 440 - 450.

Siddiqui, A.A and Chang, S., 2014. Cadmium chloride intoxication and evaluation of protein changes in Clarias batrachus (Linn). Int.J.Curr.Microbiol.App.Sci., 3(1): 787-794.

Shaffi, S.A., 1981. Mercury toxicity, biochemical and physiological alterations in nine freshwater teleosts. J. Toxicol., 8: 187-194.

Sobha, K., Poornima, A., Harini, $\mathrm{P}$ and Veeraiah, K., 2007. A study on biochemical changes in the fresh waterfish, Catla catla (Hamilton) exposed to the heavy metal toxicant cadmium chloride, 1 (iv): 1- 11.

Somaiah, K., Satish, P.V.V., Sunita, K., 
Nagaraju, B and Oyebola, O.O., 2014. Toxic impact of phenthoate on protein and glycogen levels in certain tissues of indian major carp Labeo rohita (Hamilton), Journal of Environmental Science, Toxicology and Food Technology, 8(9): 65-73.

Sprague, J.B., 1971. Measurement of pollutant toxicity to fish. III sublethal effects and safe concentrations. Water. Res., 5: 245266.

Velez, D and Montoro, R., 1998. Arsenic speciation in manufactured seafood products. J Food Prot. 61:1240-1245.

Venkata Rathinamma, V and Nagaraju, B., 2013. Impact of quinolphos on DNA and RNA content of the freshwater fish, Labeo rohita (Hamilton). International Journal of Research in Applied, Natural and Social Sciences, 1(2): 53-60.

Vutukuru, S,S and Kalpana, B., 2013. Acute effects of mercuric chloride on glycogen and protein content of Zebra fish, Danio rerio, Journal of Environmental Biology 34: $274-281$.

WHO, 1988. Chromium. In: Environmental Health Criteria, 61. World Health Organization, Geneva. pp. 1-197.
Yadav, A., Neraliya, S and Gopesh, A., 2007. Acute toxicity levels and ethological responses of Channa striatus to fertilizer industrial wastewater, Journal of Environmental biology, 28(2): 159162.

Y1lmaz, S., Türe, M., Sadıko_lu M and Duran, A., 2009. Determination of total $\mathrm{Cr}$ in wastewaters of $\mathrm{Cr}$ electroplating factories in the I. Organize industry region (Kayseri, Turkey) by ICP-AES. Environ. Monit. Assess.

Y1lmaz, A.B., Turan, C and Toker, T., 2010. Uptake and distribution of hexavalent chromium in tissues (gill, skin and muscle) of a freshwater fish, Tilapia, Oreochromis aureus, Journal of Environmental Chemistry and Ecotoxicology, 2(3): 28-33.

Zodape, G.V., 2010. Effect of Aloe vera juice on toxicity induced by arsenic in Labeo rohita (Hamilton), Journal of Applied and Natural Science, 2 (2): 300-304.

Zodape, G.V., 2011. Effect of Aloe vera juice on toxicity induced by metal, Zinc in Labeo rohita (Hamilton). Bionano Frontier, 4(1):96 - 101.

\section{How to cite this article:}

Palaniappan, R., and Muthulingam, M. 2016. Impact of Heavy Metal, Chromium on Protein Metabolism in Brain and Muscle of Freshwater Fish, Channa striatus (BLOCH). Int.J.Curr.Microbiol.App.Sci. 5(7): 638-647. doi: http://dx.doi.org/10.20546/ijcmas.2016.507.072 